\title{
Growth Arrest and DNA Damage-Inducible Protein GADD45 Beta
}

National Cancer Institute

\section{Source}

National Cancer Institute. Growth Arrest and DNA Damage-Inducible Protein GADD45

Beta. NCI Thesaurus. Code C105846.

Growth arrest and DNA damage-inducible protein GADD45 beta (160 aa, 18 kDa) is encoded by the human GADD45B gene. This protein plays a role in the regulation of cell growth, apoptosis and signaling. 